This is a self-archived version of an original article. This version may differ from the original in pagination and typographic details.

Author(s): Kotonen, Tommi

Title: Nostalgia, community and resistance : Counter-cultural politics in a Finnish skinzine

Year: 2019

Version: Accepted version (Final draft)

Copyright: @ 2019 INTELLECT LTD

Rights: In Copyright

Rights url: http://rightsstatements.org/page/lnC/1.0/?language=en

Please cite the original version:

Kotonen, T. (2019). Nostalgia, community and resistance : Counter-cultural politics in a Finnish skinzine. Journal of European Popular Culture, 10(2), 127-143.

https://doi.org/10.1386/jepc_00005_1 


\title{
Nostalgia, community and resistance: Counter-cultural politics in a Finnish skinzine
}

Tommi Kotonen, University of Jyväskylä

\begin{abstract}
Culture and community building are an essential part of the appeal of the far-right and fascist movements. Studying their cultural products is therefore important for a deeper understanding of the movement and their modus operandi. One elemental part of their culture are the so-called zines, small-scale do-it-yourself magazines intended for scene members. In certain respects, the far-right zines, skinzines, follow the forms and trends of other underground publications, especially punkzines, with which they also share the resistance identity as stigmatized and marginalized actors. However, the political visions in skinzines are more or less opposite to 'democratic zines', creating certain tension between their political goals and the general media logic. In this article, I will explore a Finnish skinzine Ukonvasama and their community, analysing the efforts to build a nationalist movement and to mobilize support in relation to a retreat to nostalgic counter-culture they also promote. Ukonvasama is both a nostalgic project of former skinheads and a political project of far-right activists.
\end{abstract}

\section{Keywords}

far-right

fascism

counter-culture

skinzines

nostalgia

resistance 
Finland

\section{Introduction}

Fascism considered as a cultural movement means seeing fascism as it saw itself and as its followers saw it, to attempt to understand the movement on its own terms. Only then, when we have grasped fascism from inside out, can we truly judge its appeal and its power. (Mosse 1999: x)

To properly understand the success and allure of fascist or far-right ideology, it is necessary to analyse how the actors within the movement saw and see their purpose and the kind of culture and identity that they want to promote. Some aspects of fascist culture have already been analysed, by George L. Mosse among others, but certain more recent forms of neo-fascist movement and their culture have been scarcely scrutinized in the scholarly literature. This applies especially to popular culture. One such product of fascist popular culture is the so-called skinzines, self-published skinhead magazines. These publications may tell interesting stories about the self-perception of the movement members, also providing a relatively rare insider view on the daily activities of the movement. Most often, these zines focus on far-right music culture, which is arguably one of the most important recruiting channels for the movement in Finland (Sallamaa 2018: 59), but they also discuss other matters. Besides promoting their culture, the skinzines are also a tool for the mobilization and recruitment of the movement - a purpose that is somewhat in conflict with the logic of the underground media and its 'will-toward-smallness' (Duncombe 1997: 168). 
In this article, I will read the Finnish skinzine Ukonvasama from the perspective of community building, focusing more closely on their mobilization efforts and changes in balance and ratio between traditional politics and subcultural community-building activities. The interpretation will be based on frame analysis, and I will study how the Ukonvasama zine proposes political diagnosis and prognosis and how their readers are motivated. The analysis is contextualized by describing the Finnish far-right in general and by exploring the key themes that the Ukonvasama represents as a collective. Along with this analysis, I will also discuss the more general questions about the political nature of zines and question how the politics and culture intertwine in Ukonvasama compared to, e.g., 'democratic zines'. The data for analysis are drawn from fifteen Ukonvasama zines published so far and other additional material published by them, including their radio show, web pages and social media accounts.

Ukonvasama provides their readers with a full spectrum of countercultural activism: topics extend from music and movie reviews to gig and demonstration reports and also political topics are discussed quite often. As typical for the zines, band interviews play a prominent role. One of the most interesting and somewhat innovative parts of the zine is the movie review section. Here, the authors read mainstream movies through their own ideology and values, finding useful guidelines for far-right resistance and also allegories of white nationalism and western values. Ukonvasama is also a curious case in modern publication culture; in the era dominated by social media and online communication, Ukonvasama is published in print format. Certain nostalgia, which is also otherwise one of the key themes in Ukonvasama, is apparent here.

From a more general perspective, the strategic decisions on organization and community may also reveal the strengths or weaknesses of the far-right movement in Finland. The analysis thus also 
illuminates the efforts to build a bridge between 'reformist' and 'revolutionary' segments of the movement and explores the role of culture in these efforts.

In describing the field in which Ukonvasama operates, I will mostly use the umbrella term far-right. This is justified because Ukonvasama as a collective tries to reach a broader nationalist community than just ideological fascists or national socialists. When the focus is on Ukonvasama's own political position, I will also refer to them as fascists or national socialists, when it is openly stated or when otherwise justified.

\section{From fanzines to skinzines}

According to a definition by Stephen Duncombe (1997: 6), 'zines are noncommercial, nonprofessional, small-circulation magazines, which their creators produce, publish, and distribute by themselves. [--] Zines as a distinct medium were born in the 1930's'. The first zines were written by science-fiction fans, then called 'fanzines', later shortened to just 'zines'. In the 1970s, punk rockers also started publishing their own fanzines, and in the 1980s, the skinheads and their farright music culture movement, RAC (Rock Against Communism), which had its roots in punk, followed the trend.

The fanzines are a product of the fan culture and are thus an integral part of the popular culture. They are written by the fans to the fans, and reflect the personal tastes of their writers; 'all fanzines are, in essence, public expressions of private pleasures' (Sanjek 2008: 419). Sometimes zines develop into mainstream, commercial publications, as has to a certain extent also happened with some skinzines (Dubowy 2002: 159). Although often unique by their design and graphic language (Triggs 2006), many fanzines are constructed from the elements of the mainstream popular culture by using the cut-and-paste technique. The skinzine analysed in this article also discusses 
mainstream popular culture artefacts from a critical, oppositional perspective. By expressing personal or collective views of the fans and taking part in the social process of genre-formation, the fanzines contribute to the critical discourse of popular music and organize musical experiences (Atton 2010).

The skinzines are often born out of necessity: nobody else writes e.g. about the RAC bands and the mainstream popular culture journals and magazines - the 'gatekeepers' according to RAC community - tend to ignore the genre altogether. This was clearly shown when one Finnish magazine, Rumba, made an exception and wrote a longish article on RAC culture in Finland. Although some were obviously critical about the way the magazine presented them as the 'other' and 'marginal', some bands were delighted that they 'received large press attention' and called it a 'historical moment' (Vapaudenristi 2016). As will be shown later in this article, friction between maintaining the authentic style and gaining the acceptance by the broader audiences is prevalent in the Ukonvasama skinzine - and this applies both to their music and politics.

The zines published by skinheads were in certain respects pretty similar to other zines, and, as observed for example by Borgeson and Valeri,

skinhead 'zines were small-run magazines, rather than mainstream ones, typically created by one, or maybe a few individuals. Most 'zines lasted only a few issues, were distributed by skinheads, by hand or through the mail, often being passed from one reader to the next. $(2018: 121)$

With the development and growth of the Internet, much of the communication between skinheads has moved online (2018). The disappearance of the printed zines seems to have happened in most 
countries by the early 2000s, and this happened in Finland too; zines have either gone online or disappeared entirely. Within other related genres, the situation is not as dire, even when considering printed zines. There are relatively numerous black metal and also noise music zines still published in print.

Skinhead magazines differ in their relation to politics. There are zines that focus mostly on celebrating their own scene, writing about music and skinhead culture. Others, which Liane M. Dubowy (2002: 146) has called politzines, may also deal with the scene and music, but in terms of far-right politics. Similarly, Borgeson and Valeri divide zines into two different categories, showing the difference between actual skinzines and more political White Power zines. As Dubowy's analysis shows, individual zines may, however, also change their orientation. To some extent, this has also happened in Ukonvasama, which started as a counter-culture or scene publication, but focused more on politics, especially in 2015 , during the so-called refugee crisis, just to retreat from politics after the situation calmed down, and the political opportunity for a broader nationalist mobilization disappeared. Political statements are, however, typically short, following the trend of the far-right underground culture in general.

As also shown by Dubowy, the line between fanzines and politzines is emphasized, and lines get blurred quite often. Counter-culture may also be interpreted politically; it is as much about politics as politzines, only with different means and strategy. Direct political statements and subcultural themes are thus not exclusive but two aspects of the same mission of identity politics.

Even though the Ukonvasama zine is intended for scene members, the contents of the zine also reflect what happens at the national political field. Subcultural identity is thus under constant negotiation and under the pressure of external events, also putting the claims for authenticity and 
identity in question, which are otherwise typical for different subcultures. At the discursive level, as I will argue, the prognostic frame of openly political claims and the calls for action are in practice supported at the subcultural or the metapolitical level, as the latter creates the motivational frame. Authenticity as a concept is rather fluid in Ukonvasama, which tries to represent the whole White Power culture, not just National Socialist Black Metal or skinhead subcultures. Claims for authenticity differ between subcultures and musical styles, and therefore, unity cannot be built around some genre-specific themes. The common political aims, conspiracy theories and nostalgia for a lost community are the uniting factors, not the culture per se, and authenticity is based on ideology, not on the purity of style.

When thinking of zines in general, Stephen Duncombe (1997: 35) has argued that 'zines are the products of individual dissenters' based on an 'underground ideal of authenticity', and therefore, he finds homologies between zines and anarchist philosophy. Chris Atton (2002: 68) also connects zine publishing to 'resistance identity' and social actors who are 'marginalized, devalued or stigmatized'. Marginal, DIY-based produced far-fight zines are also written by people who consider themselves dissenters, and these zines are not necessarily at odds with the basic anarchist ideology or resistance, even though the political direction is 180 degrees different, and individualism is seen in a different light. As Duncombe (1997: 193) notes, however, zines and all underground cultural forms are at a more or less 'pre-political' level and thus necessary but not sufficient in itself for a social change; organized political movements are needed after hegemonic takeover.

Ukonvasama oscillates back and forth between being a politzine and a skinzine. In the zines that Duncombe studied, 'most zine writers reject a strategic model of politics and communication' (1997: 36). This, however, is not the case in the zine studied here, although their revolutionary vision is not very nuanced, and irrespective of the fact that some reactions to politics are more or 
less spontaneous. Ukonvasama is also a part of a broader nationalist movement in Finland. Therefore, and to contextualize the analysis, it is worthwhile to provide a short, general description of the trends in far-right subculture and publishing in Finland.

\section{Finnish far-right culture and communication}

In the early 1990s, the most common form for expressing extremist opinions in Finland was still self-made print publications and leaflets. Punk fanzines had been around since the late 1970s, but the first skinzines appeared in the market at around the mid-1990s. Starting from late 1990s, blogs and other Internet channels mostly replaced zines, and after the Finnish Blood \& Honour zine ceased at around 2003, it took more than ten years before the Ukonvasama collective started to produce a far-right zine again. Even though publishing shifted to a new platform, the language used by the contributors did not change much. However, there was also a short wave of apparent online radicalization around the 2010 s, when forums turned more aggressive - partly due to the frustration from seeing the movement in decline (Blood \& Honour Orivesi: n.d.; cf. della Porta 1995: 284-87). Current zines continue their radical style to some extent. The first research on Finnish skinhead discussion forums and hate sites was conducted in the early 2000s, already observing the brutal style of discussion, although no incitement to direct action was found (Pekkinen 2002).

The brutal and violent language is of course not a product of the Internet. For example, in the 1990s, skinheads spread leaflets in Joensuu, urging people to kill all the Somalis (Puuronen 2011: 196). Even the most radical, revolutionary thinking is not entirely a new phenomenon, as, e.g., the Finnish National Radical Party referred to the texts of William Pierce and his Turner Diaries already in the early 1990s (Kotonen 2017). Holocaust denial, seen in Finnish forums and zines, also already in the 1990s, can arguably also be seen as a form of rhetoric supporting the use of violence. 
The ways of organizing activities have also changed from the 1990s. Far-right party organizations mostly disappeared in the early 2000s, and activity from then on was based more on 'non-political' nationalist clubs and networks. Here, one may also observe a sort of metapolitical turn, the focus shifting to the issues of culture and ethnic identity instead of direct political influence. Arguably the most important organization in this turn was Suomen Sisu, a new-right nationalist club, which promoted counter-jihadism and tried to create a respectable façade by taking rođidistance from older, explicitly racist groups like skinheads. The radical wing of the anti-immigration nationalist movement reorganized itself in 2008 by founding the Finnish chapter of the Nordic Resistance Movement, a group created after the Swedish model and openly promoting National Socialism.

From the early 2000s to the mid-2010s, a kind of minor trend among the right-wing extremists in Finland was to publish different kinds of manuals - often inspired by foreign ones or plagiarized from them - dealing at a very practical level with how ethnic cleansing or a nationalist revolution could be achieved (see, e.g., Pelastusopas 2010; Väinämöinen 2009; Kuusi 2004; Järjestö 2000; cf. Paaso 2012). Also, direct translations or originals, like the one from Max Hammer's manual and Turner diaries, were circulated, and occasionally people discussed attack plans even in the guest books of skinhead websites (Blood \& Honour Orivesi: n.d.). Besides manuals, very brutal plans and discussions were seen in discussion forums such as hh-88.com and suojeluskunta.com, both of which closed in 2013. This is possibly a generational issue in part. One factor may have been that, at that time, there were still active persons, who had direct personal experience of the wave of skinhead violence of the 1990s. What is notable in these discussions and manuals, however, is that they are straightforward and brutal, but lack clear ideological positions. They are seldom anchored to any specific form of white nationalist ideology. 
Public pressure and scrutiny and also police surveillance have possibly affected sites that are open to the public. In 2010, the first and so far the only sentence took place for the distribution of white power music (Kymenlaakso District Court 2010). Some external events, especially the Breivik attacks in 2011, also probably made some propagandists tone down their rhetoric. Even anti-refugee Facebook threads, nowadays followed also by the media, are mostly less brutal than previous forums, especially considering the exploded volume of messages, albeit some isolated cases of direct incitement to, for example, Molotov cocktail attacks against the refugees, may be found. Most radical discussions have disappeared from the public eye, and 'old-style' information may in most cases only be found in skinzines intended only for true believers.

Towards the goal of making nationalism acceptable, rhetoric plays a key part, and as an intellectual leader of the Finnish new nationalism Jussi Halla-aho (2007) has stated, so as not to look like 'stupid clowns', the most brutal forms of rhetoric should be abandoned and a more intellectual debate should be preferred. The general tendency has been, especially after a more noticeable shift to Twitter, that nationalist make targeted trolling attacks and ridicule 'the official' discourses or their political opponents.

Compared to the earlier forms, the discussion is thus not so serious or directly threatening, even though that happens as well. The strategy used has the trope of irony as its main tool, and this strategy - effectively used by Jussi Halla-aho - has become the hobby horse for what Benjamin Teitelbaum (2017: 65) has called new or reformist nationalism. This online strategy was formulated years ago, as for example in 2001, one Finnish white nationalist claimed 'ridicule is the most important weapon' against serious and stiff 'multi-culturalists' (Järjestö 2000; cf. Marantz 2018). But new media like Twitter has made this much more effective, as it tends to lead a polarized 
discussion and does not support a more balanced and elaborated discussion, Internet trolls were easier to ignore and could not flood the whole discussion that easily.

It is interesting that Ukonvasama goes against the current in many ways. The impression is that they are somewhat frustrated with 'watered down' versions of nationalism and want to take on a more serious attitude. New nationalism, alt-right and other more modern forms are seen as deviations.

\section{Ukonvasama collective and zine}

Ukonvasama (Finnish for thunderstone) is a nationalist collective based in Turku. The project started from a White Power zine published in 2015 by one person, who was then also a member of the national socialist Nordic Resistance Movement. Since then, they have broadened the scope of activities beyond zine publishing, currently including a radio programme and an online bookstore, selling nationalist literature and records. They also organize street patrols, sporting activities and martial arts training sessions. The collective claims to represent a form of leaderless resistance (see comments in Kansallinen Vastarinta 2018). Ukonvasama does not have a designated leader or even formal membership. As part of the nationalist movement in Finland, the Ukonvasama collective participates in far-right demonstrations, and, among other events, have also been present as a group at national socialist gatherings organized by the Nordic Resistance Movement (NRM).

Ideologically and stylistically, the collective appears as quite eclectic, which is also typical for skinhead groups (cf. Fangen 1998: 33).One example of this is that sometimes they refer, although not without sarcasm, to themselves as 'far-right' or 'extreme right', sometimes as 'nationalists', but mostly, they call themselves national socialists. In their visual messages, the collective uses typical fascist icons, including figures well known from international neo-Nazi scenes such as Codreanu, Primo de Rivera, Bob Matthews or Hans-Ulrich Rudel. Alongside these and Hitler memes, they 
refer to the Finnish fascist history of the 1930s regularly. Also, some nationalist leaders without any explicit connection to fascism or Nazism may appear in their canon. Through this eclecticism, they follow the style of an earlier fascist collective Musta Sydän (black heart in English), which was also a Turku-based group (Sallamaa 2018; Koivulaakso et al. 2012).

The first five issues of the Ukonvasama zine had only four pages; now, they have expanded to 32 and are published with colour front pages and are otherwise more polished compared to earlier copy machine versions. The structure of the zine has remained more or less as it was at the start; a short text by the editor-in-chief is followed by a news section, and the zines always include a review section, usually focusing on music albums, movies and literature, and occasionally also include mini-biographies of 'nationalist heroes'. Since the mid-2015, political statements and interviews have also been a common feature in Ukonvasama.

From issue 7, August 2015, an additional writer joined the zine, and a third one was added in March 2016. From issue 12 onwards, the zine has been published in cooperation with Europa Erwarche Productions. Ukonvasama is the first printed zine in Finland focusing on RAC and more generally on white power music for about ten years. Since it started, a few other zines focusing on similar ideas have also been published. These include White Power zine Swastikas Rising, which is also published by Europa Erwache Productions, and Musta Kivi, an esoteric zine focusing mostly on occult ideas behind the nationalist movement.

The Ukonvasama zine has been sold only at White Power concerts and in several online stores and brick and mortar retail stores, focused on extreme music, making it relatively hard to find. The first issues of Ukonvasama were free of charge, but were later distributed for three euro per issue to cover the copy costs. 
Even though some Finnish white power bands have shown some restraint in their texts, especially those trying to reach international markets, there appears to be no symbols or issues avoided in Ukonvasama, and the bands interviewed also quite openly discuss about their ideological positions. Swastikas are present with other far-right and Nazi symbols. Ukonvasama also promotes international groups and has advertised, for example, the National Action, even after it was banned in the United Kingdom as a terrorist organization. However, even though the zine is open about its political affiliations, some clandestinity has been maintained; article authors and record reviewers are identified only by their initials or pseudonyms. The editor in chief identifies himself only as 'El Tiburon Blanco', which is Spanish for 'white shark'.

The founder of the zine revealed some reasons behind starting the publication in their first radio programme. According to him, it started as a hobby and because he is a bit older, he did not like to read zines from the Internet but on paper. He also stated that when Ukonvasama started, there were practically no zines at all, and so he decided to put one together by himself (Vasamaradio 2018). Other information that he provided included him joining the skinhead movement fifteen years ago and still considering himself a working-class man. In 2011, he joined the NRM, first as a supporter and then as an activist. Until 2017, he also hosted radio shows for the NRM. One of the shows was called Valkoista kohinaa (White Noise), and was, according to the hosts, 'national socialist culture jamming', focusing on far-right music and counterculture. In addition, the Ukonvasama founder also hosted Riimuradio, a more political radio programme of the Nordic Resistance Movement, which started in Spring 2015 (Riimuradio 2015). The new radio project of the collective, Vasamaradio, is according to them 'a cultural programme for white identity' and approaches the theme 'through culture'. 
Interestingly, the founder of the Ukonvasama mentioned in their radio show that the zine also involves a nostalgic element; it is a retreat 'to [the] good old days of the skinhead movement'. Typically, nostalgia is associated with a loss of something and an escape from the 'realities of the present' (Duncombe 1997: 70), especially in its restorative form (Boym 2001: 41). Duncombe and others scholars (e.g. Radway 2011) often emphasize community building as an essential part in writing zines. However, from Ukonvasama's perspective, community building does not happen between zine writers and readers for an obvious reason. There is no far-right zine community in Finland, as Ukonvasama has been the only one of its kind. Therefore, Ukonvasama's efforts are necessarily nostalgic, reaching towards the 'glory days' of the movement and, to use John Clarke's well-known formulation, a 'magical recovery of community'. Several contributors and interviewees also find it necessary to mention that the movement is on the rise again.

Nostalgia is typically also related to a search for authenticity. A restorative form of nostalgia, as formulated by Boym (2001: xviii), does not even 'think of itself as nostalgia, but rather as truth and tradition'. Authenticity protects the movement from imitators, as only the insiders know the proper codes of conduct. The visions provided by the White Power movement are, however, of a darker kind, and instead of people imitating them, more often than not they want to dissociate from anything related to Nazism. But the fear of imposters is still present even within this culture, and bands that have a firm ideological position and present it openly are celebrated in the reviews. Ideological position, not genre, is also what the selection of reviewed records is based upon, and when some album is an exception to this, it is explicitly stated: 'No, this is not Nazi-music' (Ukonvasama \#6, review of Agnostic Front, n.pag.).

However, when reading Ukonvasama and especially its review section, it becomes apparent that authenticity is, although desirable, also negotiable. The authors of the zine often ask whether those 
using nationalist imagery without commitment to the movement may still benefit the movement, and typically the answer is affirmative. Using, e.g., Nazi-imagery, even when only for shock value, may lead people to study the ideology and to the 'right' path. This position seems to be present, for example, in several interviews, and a typical question is: 'For some bands, National Socialism and Fascism are used only for shocking effect, but it still may activate listeners to actual radical activities. Do you agree?' (Ukonvasama \#14; cf. also interviews in Ukonvasama \#11, \#13 and \#15). Perhaps somewhat atypical for other subcultures, here, inauthentic, non-ideological or even commercial use of their symbols is thus seen in a somewhat positive light, as it may help people come to support the ideology. This position also reflects their marginal position; whatever the support, even when inauthentic, they welcome it. Alongside the principle of leaderless resistance, it is telling about the relative weakness of the movement - making, as Jeffrey Kaplan (1997: 80) has described, a virtue of weakness and political isolation.

The use of the print format has, besides nostalgia, also deemed other elements positive. The Founder of the Ukonvasama argued that using print helps one distinguish from the 'noise' in social media, suggesting that print media does not drown so easily in the flood of information. Ukonvasama also criticizes commercialization, and the practices of zine publishing may be seen to go against this current as well, as zines are distributed free of charge or sold at a nominal cost. Considering that they see themselves as living on the margins of the society, forms of publishing that go against the mainstream also have an anarchistic element (cf. Duncombe 1997: 109). Interestingly, the founder also mentions that the use of print distances one from the so-called altright, who are, according to him, typically 'net people'.

Commenting on Polish zines, Kaja Marczewska (2019: 108) has pointed out that 'the very limitations of zines as a media form make them an important and useful safe space for radicalization 
and far-right community enlargement'. Online forums are indeed easier to follow and in some cases also easier to ban. As of writing, Ukonvasama's webpage pages have disappeared. Publishing in print 'serves as a space to manifest open and unconstrained expressions of the ideology' (Marczewska 2019: 117). Obviously, one part of the charm of print publishing is also its certain level of elitism and self-marginalization. Nationalism as a stigmatized ideology and zines as clandestine publishing may serve as a last resort of rebellion.

According to Stephen Duncombe (1997: 2), zines are radical democratic in a sense that anyone can publish them. The do-it-yourself ideology is not entirely unknown to the far-right communities either. For example, in music culture, some of the movement members emphasize the idea of 'guys from the streets' who can start producing music, even if they have little or no skill - producing something truly authentic. Going against consumer culture and professionalization, zines may also fit the far-right ideology. Furthermore, zines are heavily localized media without a broad network of distribution, which to some extent reflects their ideas of local against global. The far-right ideology, however, can be best seen in how Ukonvasama builds its community of readers and how they frame the political debate.

\section{Community in action: Frames for mobilization}

In studying how social and political movements mobilize people for their support, researchers have often used frame analysis as a starting point since Erving Goffman introduced his theory in 1974. In their well-known article, Snow and Benford (1988) suggested three core framing tasks, which they labelled as diagnostic, prognostic and action mobilization frames. By using these frames, it is possible to discern from the rhetoric used how a group intends to mobilize possible supporters and assign meaning to their tasks. 
In the following, I will analyse the Ukonvasama zine from this perspective, questioning the kind of collective that they want to build and the vision that they give potential new members or scene members in general. How Ukonvasama, which considers itself a part of the Finnish nationalist movement, is using these frames also implicates who they consider to be their target audience, additionally revealing certain important changes in who they identify as their enemy. Here, one must also note that Ukonvasama itself is not a membership organization, and therefore, the mobilization they seek benefits the entire nationalist scene.

According to their page on the Russian social media page vk.com, Ukonvasama is a "nationalist zine which has only one goal: to activate!'. In the first published issues of the Ukonvasama zine (April 2015), the editor declared that

the future of Finland lies in its youth. That's why we want to show them an alternative path instead of [the] current consumer -, drug - and multicultural society. We want to encourage them to think by themselves and to activate into action!

In the second zine, they further stressed that even though they share certain values with some other groups, Ukonvasama is an independent publication, which does not represent any movement or party.

Ukonvasama started in 2015 , and their first statements already refer to the current political situation in Finland quite often. In May 2015, the right-wing populist Finns Party entered the government, creating high hopes for the Finnish nationalist as well about the political turn to the right. Certain bitterness was also present, when they finally had the upper hand: 'At least to my ear the cry of our opponents is a real pleasure' (Ukonvasama \#4 May 2015). However, Ukonvasama had doubts about 
the Finns Party right from the start: 'Even though Ukonvasama does not share the political positions of the Finns Party, we congratulate them and remind them about their promises' (Ukonvasama \#3 May 2015).

During Summer 2015 and continuing in the autumn in particular, a relatively large number of refugees arrived to Finland. In the first issues of Ukonvasama, these events defined how they framed political problems. In their conspiratorial diagnosis, mainstream media, 'Cultural Marxists' and anarchists rule the picture as the key enemies supporting the ideology of 'multiculturalism', the welcoming of the 'mud flood of refugees' and causing rape and violence.

After the refugee crises started, nationalists began to feel increasingly disappointed with the Finns Party; when they were not able to stop the 'refugee flow' and 'invasion', Ukonvasama also changed its tone. The Finns Party, which was previously a potential ally, was beginning to be seen as a part of the system. Politics was no more an alternative: 'Undoubtedly every Finn who has cared to follow what's going on has lost one's faith in parliamentary methods' (Ukovasama \#5, June 2015).

In August 2015, the nationalist socialist Nordic Resistance Movement rioted in Jyväskylä, and several arrests followed. The arrests were seen as unjustified and arbitrary, and Ukonvasama declared, thus, that 'it is time to turn the attention towards the heart of the enemy: the ruling system'. More active measures were needed: 'We must move forward with dagger between the teeth, bomb in the hand and with a burning heart' (Ukonvasama \#7 August 2015). By the end of the year, the rhetoric sharpened even further, and in a conspiratorial tone, they identified the traditional enemy drawing strings behind the scenes: 'Multiculturalism engineered by the Jews turned the white man almost into a toothless lap dog' (Ukonvasama\#8 December 2015). 
The key problem was no more than what is currently happening in society or even the arrival of refugees in growing numbers. Now, the whole traditional Western way of life was under threat. In later issues of Ukonvasama, even more dystopian visions are brought forward, and the writers argue that the multiculturalism and tolerance are part of a historical cycle leading to the corruption and finally to the destruction of the whole Western culture, after which, a new golden era will begin. Here, they refer to the esoteric writings by, e.g., Savitri Devi and Julius Evola and their ideas about Kali Yuga, which means a dark age of mankind as a part of the cycle of history.

Hence, the initial problem setting, emphasizing the level of politics, was turned into a deterministic view of history. Ukonvasama located the problem no further than at the political level or the media but instead argued that the problem lies at the cultural or even at the cosmic level. If the refugees, multiculturalism, Islamization and population exchange were the problems, the root causes for these threats were thus discussed increasingly more on moral or fundamentalist terms rather than using a political vocabulary. Alongside this, the urge to build a personal counter culture was growing.

In 2017, the National Police Board started the process to ban the Nordic Resistance Movement in Finland, which was seen by Ukonvasama as one more sign of the system-level persecution against them and their allies. Even though their visions became deeper, enemies were still identified in the news section of the zine predominantly as communists, multiculturalists, Jewish bankers and tolerant people. This implies that the fight against the enemies happens on several levels, and that the resistance towards the 'system' is just an indication of the original conflict deepening, with a new group being added to the list of enemies; now, minorities, political enemies and representatives of the system are treated as identical, and all are seen as illegitimate (cf. Sprinzak 1991). As an example, in the December 2017 issue of Ukonvasama, the chief of the National Police Board is targeted with a photo captioned 'Finn! This swine is your enemy!' (Ukonvasama \#14, December 
2017). What is to some extent expected, the prognosis that Ukonvasama provides their readers with tends to change with new problem settings. In other words, and as Snow and Benford (1988) suggested, there is often a correlation between diagnostic and prognostic framing efforts.

The calls for action followed three somewhat intertwining paths, although the emphasis between the forms of action changes, when diagnosis reaches new levels. Celebrating the electoral success of the right-wing populist Finns Party in Spring 2015, Ukonvasama suggested that even though they do not share all the goals of the party, it was worth supporting, if not for any other reason than to make leftists and tolerant people furious.

In 2015, when more or less spontaneous anti-refugee demonstrations and street-level activism started to grow, and the Finns Party proved to be a disappointment, Ukonvasama emphasized building a collective nationalist movement. More emphasis was also placed on countercultural activism. In these efforts to call for building a broader coalition, Ukonvasama relied on several types of rhetorical frame alignment (Snow et al. 1986), including bridging by connecting their message to the goals of the demonstration movement and street patrols in 2015 and frame amplification by stressing the importance of the grass root activism.

After the spontaneous movement went into decline in early 2016, this line of activism was also abandoned, and Ukonvasama turned its attention to individual activism and guerrilla warfare. Even though the Finns Party and anti-refugee demonstrations had perhaps 'rocked the boat', Ukonvasama already in 2015 declared that 'we want to sink it' (Ukonvasama \#5 June 2015). What nationalists needed to focus on from now on was to learn battle and survival skills, build cells and be ready for action: 'Gain more strength, organize your local security troops from able men and women, and train more' (Ukonvasama \#10 March 2016). Ukonvasama quotes the words of a Finnish fascist 
writer, underlining that 'when blood has been spilled, then will the independence taste on something'. Unsurprisingly, thus, when diagnosis goes into a fundamental direction, the call for action takes on more radical forms.

Admiration shown towards rebels and guerrilla fighters had, however, been present in Ukonvasama from very early on. For example, in movie reviews, the writers constantly emphasize how movies may be read as manuals for urban guerrillas. Political struggle and coalition building thus only appear as a temporary deviation from this basic line of thought and are only a supplementary, tactical option. This, as may be noted, is also in line with the fundamentalism of the Nordic Resistance Movement for whom, for instance, participation in elections has only been a tactical move, not a change of course from their actual, revolutionary path (see esp. Lööw 2015).

According to John Pollard (2016: 417), 'generally speaking, skinzines and racist skinhead websites are not given to discussing complex, sophisticated political ideas'. This is also true when analysing the motivational framing by Ukonvasama. They do not go into detailed discussions about ideology, and there is an impression that the readers are already expected to share similar values and ideological positions. Another interesting element is, as also noted by Kaja Marczewska (2019: 115) when analysing Polish far-right zines, that 'characteristic distinctions between different farright groups are almost entirely obscured on the pages of their zines'. When building a community and a collective identity, arguably the main task of Ukonvasama, differences matter less than assumed similarities in values and positions. Therefore, it may not come as a surprise that the zine promotes and advertises several, often competing groups and parties such as the Identitarian Movement, Nordic Resistance Movement, Finns Party, Independence Party and so on. 
Heroes represented in the pages of zine are typically national socialists or fascists, albeit some other figures like Stonewall Jackson may be included, suggesting the kind of identity they want to promote by referring to these models. What is also notable is that examples and idols are most often drawn from history. Perhaps atypical for a zine promoting white power music, cult heroes of the music movement, such as the late Skrewdriver singer Ian Stuart Donaldson, are barely mentioned outside the review section. Celebrating key anniversaries is another part of the ritualistic identity building in Ukonvasama. These are often connected to the date of death of certain cult figures, and these figures are called beyond grave, much like a roll call, to announce their presence - imitating the rituals of the fascist cult of death and their ideas on resurrection and rebirth (cf. Mosse 1980; Neocleous 2015).

\section{Waiting for the Barbarians}

In the above, I have analysed the Ukonvasama collective and their zines from the perspectives of community building and mobilization. As became clear during the analysis, Ukonvasama has a relatively flexible stance regarding authenticity and its purpose in defining the borders of their subculture. When trying to reach outside their current marginal position, Ukonvasama welcomes even apparent imposters, if that may be considered beneficial for the movement. Here, they differ from, e.g., traditional skinheads, who place, among other things, much more emphasis on authenticity and see commercialization and politization as a threat to it (Ventsel 2014).

The writers of Ukonvasama are first and foremost nationalists and national socialists, and the culture they promote serves these causes. When they write about music, movies or literature, the subjects are all approached from the perspective of the movement. They even read mainstream movies through the prism of a nationalist struggle. Even though they tend to see party politics as problematic and unprincipled, they do not abhor politics in the broader sense; on the contrary, they 
welcome it and give somewhat innovative political, albeit also mythological, readings of certain pop-cultural items. While putting together some concluding remarks, I will therefore take a look at the ways in which they analyse one iconic movie, the 1982 film Conan the Barbarian, starring Arnold Schwarzenegger (Ukonvasama \#8 December 2015).

The film, which was directed, according to Ukonvasama, by 'the most fascist Jew' of Hollywood, John Milius, tells a story about the sole survivor of his perished people, Conan, who goes to battle against his main enemy and destroyer of his people, Thulsa Doom. Their reading of Conan - and some other movies - has a certain feeling of nostalgia in it, the film possibly being one of their childhood favourites. Unlike in perhaps some postmodern readings, there is no hint of irony in Ukonvasama's analysis of Conan, and the vision is conspiratorial, which is somewhat typical for nostalgic nationalism (cf. Boym 2001: 43).

In the reading by Ukonvasama, they first provide the reader with a historical allegory. Conan, his arch-enemy Thulsa Doom and Conan's ally Valeria are interpreted from the perspective of Second World War as Germany, communism and Finland. Subotai, Conan's Mongolian ally, is interpreted as symbolizing Japan. Conan beheading Thulsa Doom is interpreted as a justified victory of National Socialism, thus overturning the actual history of Second World War.

Ukonvasama then shifts the interpretation to the present time. Now, Conan is a white man, who has enough 'Aryan strength' to not give in to looming extinction. The village that he is defending is, in this interpretation, Europe, and the enemy is multiculturalism or Islam. Tolerant people are helping the enemy and thus must be destroyed. A rebelling slave, Conan, shows the way for the awakening of Europe or otherwise a 'war plan for the nationalist white man'. In reference to Turner Diaries, 
Ukonvasama declares that 'the day of the rope will [a]wait' all those who enable the corrupt behaviour of coloured 'sub-humans'.

In their reading of Conan, Ukonvasama combines all the elements and values present in their community: tradition, warrior mentality, eternal values, national character, loyalty and community. The enemy is always someone or something about to destroy the national unity, old traditions and hierarchies by mixing categories and forms of life in an unnatural way. Even though the battle is waged on the political and on the cultural front, it all boils down to protecting one's race and culture from impure elements. In this battle, especially when condemned and on the margins of society, one cannot be too restrictive when selecting one's allies, and nationalists have to rely on international cooperation.

To some extent countering the efforts to build a united front, which Ukonvasama seems to despise, and contrary to the zines that Duncombe has analysed, is the use of irony. In the Ukonvasama zines, there is a notable lack of ambivalence, transgression and crossing boundaries so prevalent in 'postmodern' forms of nationalism, like the alt-right or as it is currently in Finnish politics, especially in the Finns Party and its leader Jussi Halla-aho, who has effectively chosen irony as his political style. When giving punches to the 'reds', the Finns party may be lauded, but in the end, they are as corrupt and inauthentic as the multiculturalists. Furthermore, even though occasionally accepting inauthentic forms of presentation for shock effect, which enables people to come to the 'source', it is the 'old school' style, 'purity' and true, raw attitude what they foremost promote. In this sense, coming back to the old forms of publishing also reflects this nostalgia and certain elitism. 
From the political perspective and following the logic of the underground, Ukonvasama thus effectively divides the nationalist movement into reformist and revolutionary camps, despite initial efforts to other directions. This is also shown when studying who distributes and supports their zine. For example, on their current social media page onvk.com, they seem to have only a handful of followers; all of them belong to the revolutionary, subcultural segment of the movement. The support they will possibly gain in the future thus most likely comes from the same subcultural scene they are already a part of, not by broadening its limits but by strengthening their commitment. Therefore, the Ukonvasama community and zine again appears after the political opportunity for broader mobilization is closed, as a retreat to a nostalgic, imaginary community.

\section{Acknowledgements}

This work was supported by the Academy of Finland under grant number 311877.

\section{References}

Atton, C. (2002), Alternative Media, London: Sage. (2010), 'Popular music fanzines: Genre, aesthetics, and the "Democratic Conversation"', Popular Music and Society, 33:6, pp. 517-31.

Blood \& Honour Orivesi (n.d.), 'Guest book', https://web.archive.org/web/20130111062425/http://www.freebok.net/books/bhvieras/view.html. Accessed 14 February 2019.

Borgeson, K. and Valeri, R. (2018), Skinhead History, Identity, and Culture, Abingdon: Routledge. 
Boym, S. (2001), The Future of Nostalgia, New York: Basic Books.

della Porta, D. (1995), Social Movements, Political Violence, and the State: A Comparative Analysis of Italy and Germany, Cambridge: Cambridge University Press.

Dubowy, L. M. (2002), 'Von Party bis Propaganda: RechtsRock-Fanzines zwischen Subkultur und Politik', in C. Dornbusch and J. Raabe (eds), RechtsRock. Bestandsaufnahme und Gegenstrategien, Münster: Unrast Verlag, pp. 145-166.

Duncombe, S. (1997), Notes from Underground: Zines and the Politics of Alternative Culture, London: Verso.

Fangen, K. (1998), 'Right-wing skinheads - nostalgia and binary oppositions', Young, 6:3, pp. 3349.

Halla-aho, J. (2007), 'Olavi Mäenpää ja Varsinais-Suomen vaalipiiri', Scripta - Kirjoituksia uppavasta lännestä, 7 March, http://www.hallaaho.com/scripta/olavi_maenpaa_ja_varsinaissuomen_vaalipiiri.html. Accessed 14 February 2019.

Järjestö (2000), 'Valkosolut', Järjestö 2000, n.d., https://web.archive.org/web/20010802152358/http://pappa.20m.com:80/19.htm. Accessed 14 February 2019.

Kansallinen Vastarinta (2018), 'Vasamaradio haastatteli Antti Niemeä', Kansallinen Vastarinta, 3 September, https://www.vastarinta.com/vasamaradio-haastatteli-antti-niemea/. Accessed 15 February 2019. 
Kaplan, J. (1997), 'Leaderless resistance', Terrorism and Political Violence, 9:3, Fall, pp. 80-95.

Koivulaakso, D., Brunila, M. and Anderson, L. (2012), Äärioikeisto Suomessa, Helsinki: Into.

Kotonen, T. (2017), 'Kansallinen radikaalipuolue ja angloamerikkalaiset vaikutteet', Historiallinen aikakauskirja, 115:3, pp. 317-331.

Kuusi, A. (2004), 'Suoran toiminnan aakkoset', Kansallissosialistinen kirjasto, n.d., https://web.archive.org/web/20040422060809/http://www.kansallissosialismi.com:80/abc.htm. Accessed 15 February 2019.

Kymenlaakso district court (2010), judgment in case R10/632, 3 June 2010.

Lööw, H. (2015), Nazismen i Sverige 2000-2014, Stockholm: Nordfront.

Marantz, A. (2018), 'Inside the Daily Stormer's style guide', The New Yorker, 8 January, https://www.newyorker.com/magazine/2018/01/15/inside-the-daily-stormers-style-guide. Accessed 14 February 2019.

Marczewska, K. (2019), 'Zine publishing and the polish far right', in M. Fielitz and N. Thurston (eds), Post-Digital Cultures of the Far Right: Online Actions and Offline Consequences in Europe and the US, Bielefeld: transcript Verlag, pp. 107-20. 
Mosse, G. L. (1999), The Fascist Revolution: Toward a General Theory of Fascism, New York: Howard Fertig.

Mosse, G.L. (1980), Masses and man: nationalist and Fascist perceptions of reality. New York: Howard Fertig.

Neocleous, M. (2005), 'Long live death! - fascism, resurrection, immortality', Journal of Political Ideologies, 10:1, pp. 31-49.

Paaso, M. (2012), Anders Behring Breivikin manifesti '2083: Eurooppalainen itsenäisyysjulistus' esimerkkinä vastajihadistisesta tekstistä, Helsinki: Suojelupoliisi, https://www.supo.fi/instancedata/prime_product_julkaisu/intermin/embeds/supowwwstructure/6407 0_Maria_Paaso_VASTAJIHAD_Supo_tutkimusraportti_1_2012.pdf?d1fb03627355d488. Accessed 14 February 2019.

Pekkinen, A.-M. (2002), 'Viesti valkoisesta vallasta välittyy verkossa', in P. Raittila (ed.), Etnisyys ja rasismi journalismissa, Tampere: University of Tampere, pp. 183-199.

Pelastusopas (2010), palautus.org, n.d., http://web.archive.org/web/20100307141643/http://palautus.org/pelastusopas.html. Accessed 15 February 2019.

Pollard, J. (2016), 'Skinhead culture: The ideologies, mythologies, religions and conspiracy theories of racist skinheads', Patterns of Prejudice, 50:4\&5, pp. 398-419. 
Puuronen, V. (2011), Rasistinen Suomi, Helsinki: Gaudeamus.

Radway, J. (2011), 'Zines, half-lives, and afterlives: On the temporalities of social and political change', Publications of Modern Language Association, 126:1, January, pp. 140-50.

Riimuradio (2015), 'Episode 1, “Juuso Tahvanainen/Suomalainen vapaustaistelu - NYT!”,, Riimuradio, 1 May,, https://www.youtube.com/watch?v=-EAJ5ocIfn0. Accessed 14 February 2019.

Sallamaa, D. (2018), Ulkoparlamentaarinen äärioikeistoliikehdintä ja maahanmuuttovastaisuus 2010-luvun Suomessa, University of Helsinki and Publications of the Faculty of Social Sciences 97, Helsinki: Unigrafia.

Sanjek, D. (2008), 'Fans' notes: The horror film fanzine', in E. Mathijs and X. Mendik (eds), The Cult Film Reader, Maidenhead: Open University Press, pp. 419-28.

Snow, David A. and Benford, Robert D. (1988), 'Ideology, frame resonance, and participant mobilization', in B. Klandermans, H. Kriesi and S. Tarrow (eds), From Structure to Action: Social Movement Participation Across Cultures, Greenwich, CT: JAI Press, pp. 197-217.

Snow, David A., Burke Rochford, R., Jr, Worden, Steven K. and Robert, D. Benford (1986), 'Frame alignment processes, micromobilization, and movement participation', American Sociological Review, 51:4, pp. 464-81. 
Sprinzak, E. (1991), 'Right-wing terrorism in a comparative perspective: The case of split delegitimization', in T. Bjørgo (ed.), Terror From the Extreme Right, London: Frank Cass \& Co, pp. $17-43$.

Teitelbaum, Benjamin R. (2017), Lions of the North: Sounds of the New Nordic Radical Nationalism, Oxford: Oxford University Press.

Triggs, T. (2006), 'Scissors and glue: Punk fanzines and the creation of a DIY aesthetic', Journal of Design History, 15:1, pp. 69-83.

Väinämöinen (2009), ‘Operaatio Ulos! - opas isänmaallisille suomalaisille’, Hommafantasia 2000, n.d., https://www.docdroid.net/LwWRd4j/hommafantasia-2000.pdf. Accessed 15 February 2019.

Vapaudenristi (2016): ‘Medianäkyvyys/media coverage', Facebook, 26 May, https://www.facebook.com/vapaudenristi/photos/a.425577770916373/718731561600991/?type=3\& theater. Accessed 30 July 2019.

Vasamaradio (2018), 'Pilotti/Juontajat esittäytyvät', Vasamaradio, 31 October, https://archive.org/details/pilootti. Accessed 15 February 2019.

Ventsel, A. (2014), “"That old school Lonsdale”: Authenticity and clothes in German skinhead culture', in R. Cobb (ed.), The Paradox of Authenticity in a Globalized World, London: Palgrave Macmillan, pp. 261-75.

\section{Contributor details}


Tommi Kotonen, Ph.D., is a political scientist at the University of Jyväskylä, Finland, and research coordinator of the Academy of Finland profiling area Crises Redefined: Historical Continuity and Societal Change. His publications include work on radical nationalist symbols and fashion, political violence, Swedish-speaking Finns and right-wing extremism in Finland and Finnish radical nationalism in the 1990s. Kotonen's latest monograph, Politiikan juoksuhaudat (Atena 2018), analysed the development of right-wing extremism in Finland during the Cold War.

Contact:

Tommi Kotonen, University of Jyväskylä, Department of Social Sciences and Philosophy, PO Box 35, FI-40014 Finland.

E-mail: tommi.kotonen@jyu.fi

https://orcid.org/0000-0003-2348-2519 